\title{
FEDERAL TAXATION: TAX COURT SANCTIONS DEFERRED ACCRUAL OF FINANCE CHARGES SUBJECT TO A POSSIBILITY OF ABATEMENT
}

$\mathrm{I}_{\mathrm{T}}$ I HAS BEEN axiomatic since the incorporation of the accrual basis in income tax accounting ${ }^{1}$ that a contingent right to income cannot be accrued. 2 The right to a specified amount of income ${ }^{3}$ is said to be certain for tax purposes only if all the events necessary to fix that right to payment have occurred. 4 Known as the "all events" test, this requirement of an unconditional right to payment has been criticized for its failure to conform to sound business accounting practice. ${ }^{5}$ In Luhring Motor Co., ${ }^{6}$ the Tax Court held that finance

\footnotetext{
1 The Revenue Act of 1913 taxed "the entire net income arising or accruing from
} all sources in the preceding calendar year...." Revenue Act of 1913, ch. $16 \S$ II, 38 Stat. 166. This language, however, was interpreted to mean that only income actually received could be taxed. Edwards v. Keith, 231 Fed. 110, 112-13 (2d Cir. 1916), cert. denied, 243 U.S. 638 (1917); United States v. Christine Oil \& Gas Co., 269 Fed, 458 (W.D. La. 1920). The accrual method of income tax accounting was incorporated into the tax law three years later. Revenue Act of 1916, ch. $493 \S 13$ (d), 39 Stat. 771. Today, a taxpayer is permitted to compare income under any method of accounting which clearly reflects his income. INT. REv. CODE OF 1954, $\$ 446$ (a). The accrual method is expressly mentioned as acceptable. INT. REv. CoDE of 1954, $\$ 446$ (c) (2). See also Treas. Reg. $\$ 1.446-1$ (c)(1)(ii) (1957). See generally Goldstone, Aspects of Recognition of Taxable Income upon the Accrual Basis, 12. TAxes 474 (1934).

${ }^{2}$ E.g., Barham v. United States, 256 F.2d 456, 457 (4th Cir. 1958); Breeze Corp. v. United States, 117 F.Supp. 404, 407 (Ct. Cl. 1954) (dictum); 2 MERTENs, LAw OF IEDERAL. INCOME TAXATION $\$ 12.62$ (rev. ed. 1961) [hereinafter cited as MERTENs]; Comment, Accrual: The Uncertain Concept of Certainty-A History of the All Events Test, $21 \mathrm{U}$. CHI. L. REv. 293 (1954).

- The amount of income involved must be capable of determination with reasonable accuracy. Treas. Reg. $\$ 1.446-1$ (c) (1) (ii) (1957); 2 MERTENs $\$ 12.61$ at 159 (1956); cf. Gray, Synchronizing Deductible Taxes and Taxable Income, 9 U. CHr. L. REv. 442, 451 (1942).

" "Generally under an accrual method, income is to be included for the taxable year when all the events have occurred which fix the right to receive such income.... The method used by the taxpayer in determining when income is to be accounted for will be acceptable if it accords with generally recognized and accepted income tax accounting principles and is consistently used by the taxpayer from year to year." Treas. Reg. \$ 1.446-1 (c) (1) (ii) (1957). See, e.g., Lucas v. North Texas Lumber Co., 281 U.S. 11 (1980) (income from sales contract cannot be accrued until vendee is uncondi. tionally liable for purchase price); United States v. Utah-Idaho Sugar Co., 96 F.2d 756, 759 (10th Cir. 1938).

The all events test is also applied to deductions for expenses. Treas. Reg. $\$ 1.446$. I (c) (I) (ii) (1957).

s Freeman, Tax Accrual Accounting for Contested Items, 56 MIcH. L. REv. 727, 73233 (1958). The author asserts that the test itself, as developed by the Supreme Court, is in harmony with sound business accounting practice, but that its application by the lower courts violates good accounting sense. Contra, Holland, Accrual Problems in 
charges attributable to a contract right did not meet the all events requirement when, owing to business custom, such charges were subject to possible abatement.

In 1955 Luhring Motor Company, an accrual basis taxpayer, entered into numerous conditional sales contracts including provisions for both a sales price and a finance charge. The finance charges were prorated over the lifetime of the contracts, ${ }^{7}$ but in the event of early payment of the total sales price, the remaining charges were customarily abated. ${ }^{8}$ The Commissioner declared a tax deficiency for 1955 on the ground that the right to receive the total finance charges was fixed as of the date the contracts were executed. ${ }^{9}$ This would have required the taxpayer to accrue all finance charges in the taxable year of the contracts' execution. The Tax Court, however, rejected this analysis and found that the right to such

Tax Accounting, 48 MICH. L. REv. 149, $181-82$ (1949). Professor Holland argues that some departure from accounting principles is acceptable if the all events test is to provide a measure of certainty in an otherwise uncertain area.

Criticism lately has also centered around the rules that have been applied to two particular types of cases: those in which the taxpayer has received income prior to his legal right to receive such; and those in which the taxpayer sets up a reserve in anticipation of subsequent expenditures. See Comment, 61 MicH. L. REv. 148, 155 (1962); Note, 61 HARv. L. REv. 1010 (1948). To govern the former situation, the courts have developed the "claim of right" doctrine, which provides that a person who rcccives payments under a claim of right, and who is under no restriction as to the disposition of those payments, has received income for the purposes of accrual income tax accounting. E.g., Automobile Club v. Commissioner, 353 U.S. 180, 188-90 (1957) (advance receipt of membership dues); United States v. Schlude, 372 U.S. 128 (1963); South Dade Farms, Inc., v. Commissioner, 138 F.2d 818 (5th Cir. 1943) (advance rentals); Curtis R. Andrews, 23 T.C. 1026, 1032-33 (1955); see 2 MERTENS $\$ 12.103$, at 315 n.53, and authoritics cited therein. This doctrine has been attacked on the grounds that it does not allow a proper matching of income and related expenditures. Beacon Publishing Co. v. Commissioner, 218 F.2d 697, 700-01 (10th Cir. 1955); Heffern, Claim of Right and Other Tax Doctrines Are Distorting Proper Accounting, $5 \mathrm{~J}$. TAxation 20 (1956). However, the rule is justified on the grounds of federal administrative convenience, the desirability of a set standard, and a reluctance to run the risk of subsequent taxpayer insolvency. See Behren, Prepaid Income-Accounting Concepts and the Tax Law, 15 TAX L. Rev. 343, 363-65 (1960). The claim of right doctrine has been expressly repudiated in subscription and membership dues cases. INT. REv. CODE OF 1954, §§ 455-56.

For a discussion of the reserve cases, see note 35 infra.

42 T.C. 732 (1964).

"According to the court, this was "in accord with the accounting standards and practiccs prescribed by the American Institute of Certified Public Accountants." Id. at 738.

"Although there is no express provision for abatement of finance charges in the contract, the evidence is clear that it was the custom of petitioner, as well as other automobile dealers in the environs of the [area]... to abate the remaining unpaid finance charges for the unexpired term of the contract." Id. at 743.

Id at 739 . 
charges was conditioned upon the absence of early payment due to the custom of abatement. ${ }^{10}$ Thus, the right to future finance charges was not fixed within the meaning of the all events test, and the court held that these charges should be accrued ratably over the life of the contracts as payments became due. ${ }^{11}$

Historically, the accrual basis for income tax accounting was established to avoid the distortion of income resulting from the use of the cash basis by all taxpayers. ${ }^{12}$ The combination of a graduated tax rate with fixed periods for the determination of taxable income necessarily imposed a hardship upon those parties whose receipt of income was not spread evenly over the same period of time as the income was earned. The all events test, on the other hand, was subsequently developed to prevent the use of those business accrual methods which tended either to distort income in the taxpayer's favor or to involve the Government in a process of "interminable accounting." 13

The all events test is phrased in terms of the right to receive a specified amount of income. ${ }^{14}$ Courts have held that income should be accrued at the moment when the taxpayer has acquired a legally enforceable right to receive same..$^{15}$ If the legal right is contested ${ }^{10}$

\footnotetext{
${ }^{10}$ In summarizing the evidence, the court found that "purchasers in the area were familiar with this custom with respect to conditional. sales contracts in the automotive business, and petitioner would have been unable to compete for their business if it bad not abated such charges." Id. at 743.

${ }^{11}$ Id. at 739,746 . As a preliminary to the bulk of its decision the court found that the finance charges were in part interest and in part a carrying charge, and summarily deferred accrual of the former on the grounds that interest by its nature accrues ratably. Id. at 742 .

12 Goldstone, supra note 1, at 474. For example, a building contractor who received a lump-sum payment for a construction job lasting several years would be taxed, under the cash basis, on all income received in one year, even though his business expenses deductions and work were attributable to a period of years. See In re Newman, 94 F.2d 108, 110 (6th Cir. 1938).

${ }^{13}$ 1919-1 Cum. Buld. 217, 218; see G. E. Holmes, Federal Taxes (1923 ed.). It has also been suggested that the all events test was developed because of the failure of taxpayers to present enough evidence to the courts indicating that their methods clearly refiected income. Reiling, Tax Accounting for Repricing and Other Reserves, 31 TAXEs 990, 993 (1953).

16 Regulation quoted note 4 supra.

${ }^{15}$ E.g., United States v. Delta Air Lines, 255 F.2d 501 (5th Cir. 1958); United States v. Utah-Idaho Sugar Co., 96 F.2d 756 (10th Cir. 1938); H. Liebes \& Co. v. Commissioner, 90 F.2d 932 (9th Cir. 1937).

${ }^{10}$ E.g., Swastika Oil \& Gas Co. v. Commissioner, 123 F.2d 382, 384 (6th Cir. 1941); H. Liebes \& Co. v. Commissioner, supra note 15; Cold Metal Process Co., 17 T.C. 916 (1951).
} 
or the amount cannot be determined with reasonable accuracy, ${ }^{17}$ all the events necessary to fix the right have not occurred. One notable exception to the test has been presented in cases where a legal right to receive rents or interest was not accrued due to a substantial probability that the income would never be received. ${ }^{18}$ In these cases, probable nonpayment was attributable to the debtor's or lessee's financial distress. ${ }^{19}$

Only two cases prior to Luhring had dealt with the specific issue of when to accrue finance charges, and in both instances the courts held that execution of a conditional sales contract had not satisfied the all events test. ${ }^{20}$ In both instances, the right to collect finance charges was subject to a clear legal right of abatement by the purchaser. ${ }^{21}$ The parties had expressly stipulated in the sales contract that early payment of the purchase price would abate remaining finance charges, ${ }^{22}$ and in one case this right was conferred upon purchasers by a state statute. ${ }^{23}$ In relying upon these cases, the

${ }^{17}$ See note 3 supra. In Luhring, the Tax Court sought to justify deferred accrual by intimating that the total amount of the finance charges were not reasonably determinable as long as they were subject to abatement. 42 T.C. at 741. See also Gunderson Bros. Eng'r Corp., 42 T.C. 419, 427 (1964). Although the uncertainty of abatement may lend support to this contention from a strict accounting viewpoint, it begs the question for tax purposes. Since the amount of finance charges were fixed in the contracts, the total amount of such charges could be easily calculated if the court found that the right to such charges was fixed.

${ }^{18}$ O'Sullivan Rubber Co., 42 B.T.A. 721, $a c^{\prime} d, 120$ F.2d 845 (2d Cir. 1941) (interest); Oregon Terminals Co., 29 B.T.A. 1332 (1934) (rents); see 2 MERTENs 281 \& n.41 (interest), 288 \& n.64 (rents).

${ }^{10}$ O'Sullivan Rubber Co., supra note 18, at 722-23; Oregon Terminals Co., supra note 18 , at 1332. One court has rationalized the exception by stating that under the all events test, interest income "is not accruable as long as reasonable doubt exists as to the amount that is collectible by reason of the financial condition or insolvency of the debtor." Clifton Mfg. Co. v. Commissioner, 137 F.2d 290, 292 (4th Cir. 1943). This justification should not be taken to imply that these cases are consistent with the all events test; the uncertainty of collection does not affect the existence of a legal right to collect a specified amount. See Spring City Foundry Co. v. Commissioner, 292 U.S. 182, 184-85 (1934).

Where the certainty of collection is subject to the political whims of a foreign government, it need not be accrued. Cuba R.R., 9 T.C. 211 (1947). It would appear, however, that state governments are presumed to meet their financial obligations. Georgia School-Book Depository, Inc., I T.C. 463 (1943).

${ }^{20}$ Smith Motors, Inc. v. United States, 8 Am. Fed. Tax R.2d 5336 (D. Vt. 1961); Gunderson Bros. Eng'r Corp., 42 T.C. 419 (1964).

${ }^{21}$ Smith Motors, Inc., supra note 20, at 5338-39. Gunderson Bros. Eng'r Corp., supra note 20 , at $427-28$ \& n.14.

${ }^{22}$ Smith Motors, Inc. v. United States, 8 Am. Fed. Tax R.2d 5336, 5338 (D. Vt. 1961); Gunderson Bros. Eng'r Corp., 42 T.C. 419, $421-22$ (1964).

${ }^{28}$ ORE. REv. STAT. \$ 83.620 (1953); see Gunderson Bros. Eng'r Corp., supra note 22. 
Luhring court found that purchasers were entitled to abatement because parties must be presumed to know and incorporate into written contracts those business customs generally prevailing in the area. ${ }^{24}$

The court, however, did not purport to rely upon the Virginia law of contracts to determine whether purchasers would as a matter of law be entitled to abatement. ${ }^{25}$ All the taxpayer's contracts expressly provided that the parties agreed only to those terms contained in or annexed by writing to the written document. ${ }^{28}$ None alluded to the possibility of abatement. Thus, an attempt to enforce an abatement privilege might have been frustrated by strict application of the parol evidence rule. ${ }^{27}$ On the other hand, there is authority in Virginia case law which may support the Tax Court's assumption that generally accepted business customs may be incorporated into contracts. ${ }^{28}$

Assuming, however, that local law would not have enforced a right to abatement, it is arguable that the right to receive income should not be accrued if it would significantly distort the taxpayer's income. ${ }^{29}$ The Tax Court intimated that immediate accrual would

2442 T.C. at 744.

${ }^{25}$ No mention was made of state law. Instead, the Tax Court relied on pre-Erie federal law (citing Hostetter v. Park, 137 U.S. 30, 40 (1890)) for the proposition that business customs could be incorporated in contracts. 42 T.C. at 744 .

${ }^{20}$ The contracts read as follows: "This agreement constitutes the entire agreement between the parties, and no waiver or modification of its terms shall be valid unless written upon or attached to this contract and signed by the parties. No representations or warranties are made by Seller that are not contained in this agreement." 42 T.C. at 735 .

27 Under local law (Virginia) the parol evidence rule is accorded considerable weight, Payne v. Jennings, 144 Va. 126, 136, 131 S.E. 209, 212 (1926), and the courts specifically bar the introduction of parol evidence as to new terms that vary the express stipulations of a written contract. E. I. Du Pont De Nemours \& Co. v. Kelly, 252 Fed. 523 (4th Cir. 1918); Protestant Episcopal High School v. Parrish, 168 Va. 108, 190 S.E. 146 (1937); Jones v. Franklin, 160 Va. 266, 168 S.E. 753 (1933).

${ }^{28}$ Although the parol evidence rule has been applied strictly by the Virginia courts, see note 27 supra, there is precedent tending to support the Tax Court's opinion in the area of business customs. [In one instance where the parties to a contract had not specified the quality of lumber to be shipped, the Virginia Supreme Court stated: "Parol evidence is competent to annex to a contract a custom or usage of the business and locality known to the parties, or so generally and well settled as to be presumed to be known to them, and with reference to which they must be deemed to have contracted." Arkla Lumber \& Mfg. Co. v. West Virginia Timber Co., 146 Va. 641, 650-51, 132 S.E. 840, 842 (quoting Browne, PArole Evidence $\$ 57$, at 216 (1893)). A distinction between this situation and Luhring might be that parol evidence was required to clarify ambignous terms of the contract, whereas clarification of the price terms was unnecessary in Luhring.

${ }^{20}$ The purpose of the all events test was to avoid the distortion of income, see 
produce such a distortion by taxing income which might never be received, ${ }^{30}$ and thus the decision may rest squarely on a policy basis. The assertion that the taxpayer would be taxed on income which might never be received, however, would not appear sufficient to indicate a distortion of income under traditional tax accrual accounting. If the Commissioner's position in Luhring was sustained, the taxpayer still would be entitled to obtain a compensating adjustment by deducting abated charges as business expenses ${ }^{31}$ or business losses ${ }^{32}$ in the year of abatement. It is not inconsistent with tax policy to tax income which might never be received. The same treatment, for example, is accorded any business which anticipates a substantial percentage of its accounts receivable to be negated by bad debts. ${ }^{33}$ If the taxpayer is fearful of bunching bad debts in a bad year, he is permitted by the Internal Revenue Code to incur the deduction ratably over a period of years through the use of a reserve. ${ }^{34}$ The predominant view of courts of appeals would permit the use of reserves for other types of business expenses when reasonably calculated and well-documented. ${ }^{35}$

text accompanying notes 13-14 supra, and it would seem anomalous to insist upon a strict application of the test where it would not clearly reflect income.

${ }^{30} 42$ T.C. at 745-46. The Tax Court relied upon language to the same effect in Smith Motors, Inc. v. United States, 8 Am. Fed. Tax P.2d 5336, 5338 (D. Vt. 1961) and Gunderson Bros. Eng'r Corp., 42 T.C. 419, 427-28 (1964).

${ }^{31}$ INT. REV. CODE OF 1954, $\S 162$ (a). "To be deducted under this section of the Code, the expenses must be "ordinary" and "necessary" expenses of the business. The Tax Court found that abatement was necessary as a matter of business survival. See note 10 supra. It also determined that nost automotive dealers in the area adhered to the custom of abatement. See note 8 supra. The general test for determining what is an "ordinary" expense is whether another business would do the same thing. See, e.g., Commissioner v. Motch, 180 F.2d 859 (6th Cir. 1950).

${ }_{82}$ INT. Rev. CoDe of 1954, $\$ 165$ (a), (c) (1). Losses sustained by a corporation are deductible under $\S 165(\mathrm{a})$, and losses of an individual incurred in the conduct of a trade or business are deductible under $\S 165$ (c) (1). The deductions for bad debts under $\S 166$ and losses are mutually exclusive. Katherine J. Hanes, 2 T.G. 213 (1943) and cases cited therein.

as INT. REv. CODE OF 1954, § 166.

34 INT. REv. CoDE OF 1954, §166 (c).

${ }^{86}$ In the reserve cases, some courts have retained the "all events" test and disallowed accrual of a contingent liability. Brown v. Helvering, 291 U.S. 193 (1934); Shapleigh Hardware Co. v. United States, 81 F.2d 697 (8th Cir. 1936); Readers' Pub. Corp. v. United States, 40 F.2d 145 (Ct. Cl. 1930); Tennessee Consol. Coal Co., 15 T.C. 424, 430-31 (1950). In recent cases, however, many of the circuit courts have permitted the use of well-documented reserves to accrue expenses ratably. Denise Coal Co. v. Commissioner, 271 F.2d 930, 936-37 (3d Cir. 1959); Schuessler v. Commissioner, 230 F.2d 722 (5th Cir. 1956); Ohmer Register Co. v. Commissioner, 131 F.2d 682 (6th Cir. 1942); see Hilinski v. Commissioner, 237 F.2d 703 (6th Cir. 1956); Central Cuba Sugar Co. v Commissioner, 198 F.2d 214 (2d Cir. 1952). 
Thus, immediate accrual of income would not have distorted the taxpayer's income to a greater extent than the immediate accrual of income subject to the probability of bad debts. Another line of authority not mentioned by the Tax Court, however, lends solid support to the result obtained in Luhring. Courts of appeals have recently recognized that methods of reporting income generally accepted within an industry "should not be condemned for some abstruse legal reason, but only when they fail to reflect income."38 Since the statute sanctions the use of any method of accounting which is consistent and clearly reflects income, ${ }^{37}$ it would have been erroneous in Luhring to require immediate recognition of finance charges merely because the all events test was satisfied. The only question presented in the case, therefore, would have been whether the method was consistently used by the taxpayer..$^{38}$

The Luhring situation highlights another instance where generally accepted accounting practices ${ }^{39}$ may differ from established tax accrual policy. ${ }^{40}$ Unfortunately, the Tax Court tended to obscure the basic issue by failing to posit its decision on an interpretation of

so Pacific Grape Products Co. v. Commissioner, 219 F.2d 862, 869 n.10 (9th Cir. 1955). In Pacific Grape, the taxpayer used the accrual method to report income and adopted the industry practice of accruing income for all ordered goods regardless of whether title had passed or the goods had been packaged and shipped. The court quoted the following passage from a dissenting opinion in the Tax Court: "The practice of disapproving consistent accounting systems of long standing seems to me to be exceeding all reasonable bounds.... Methods of keeping records do not spring in glittering perfection from some unchangeable natural law but are devised to aid business men in maintaining sometimes intricate accounts. If reasonably adapted to that use they should not be condemned for some abstruse legal reason, but only when they fail to reflect income. There is no persuasive indication that such a condition exists here. On the contrary, a whole industry apparently has adopted the method used by petitioner." Pacific Grape Products Co., 17 T.C. 1097, 1110.11 (1952).

The Pacific Grape doctrine has been expressly approved in analogous situations, viz., the accrual of expenses, by at least two other circuits. Commissioner v. Fifth Avenue Coach Lines, Inc., 281 F.2d 556, 562 (2d Cir. 1960); Schuessler v. Commissioner, supra note 35 , at 724. At first the Tax Court appeared to recognize the doctrine's validity in the context of industry-wide accounting practices, see Pacific Vegetable Oil Corp., 26 T.C. 1, 19 (1956), but in a subsequent case inconsistent positions of the judges reflected uncertainty regarding its application. Automobile Club of New York, Inc., 32 T.C. 906, 916, 920-22 (1959) (concurring and dissenting opinions). In Luhring, this uncertainty was manifested in the court's reluctance to apply the doctrine when a convenient alteruative such as the all events test was available. In light of the Luhring opinion's shortcomings, it appears that the court is torturing one test to avoid another.

${ }^{87}$ INT. REV. CODE OF 1954, § 446 (a), (b).

${ }^{8 B}$ In Luhring, the taxpayer had discounted his conditional sales contracts to a finance company prior to 1955 . Therefore, this was the first year in which he had adopted the method of accruing finance charges employed by the industry.

See note 7 supra.

10 See note 5 supra. 
state law. Moreover, by adhering to strict accrual concepts, the court avoided a decision on the alternative ground that accounting procedures which are generally accepted by the accounting profession as well as the business community should be acceptable for tax accounting purposes if used consistently and if such procedures clearly reflect income. 